\title{
APPLICATION OF ARTIFICIAL NEURAL NETWORKS TO THE TECHNICAL CONDITION ASSESSMENT OF WATER SUPPLY SYSTEMS
}

\author{
ZASTOSOWANIE SZTUCZNYCH SIECI NEURONOWYCH \\ DO OCENY STANU TECHNICZNEGO SIECI WODOCIĄGOWEJ
}

\begin{abstract}
The paper explains a method for discerning the parts of a water supply system in need of renovation. The results are based on technical data collected over the last twenty one years, concerning more than two hundred sections of both renovated and nonrenovated pipelines. In the study, an appropriately prepared data set was used for training an artificial neural network (ANN) in the form of a multilayer perceptron (MLP). Further comparison between the responses of the trained MLP and the decisions made by human experts showed satisfactory consistency, although $15 \%$ of the database records produced certain discrepancies. The presented method can help create an expert system capable of supporting failure-free operation of a water distribution system.
\end{abstract}

Keywords: water supply system, pipeline renovation, multilayer perceptron

\section{Introduction}

Water supply systems are responsible for the intake, treatment and supplying water to various recipients. Such systems usually comprise a water intake, purification facilities, transit pipelines, pumping stations, storage facilities and a distribution network. In Poland, households consume $73 \%$ of municipal water. It is important that the end user be not only provided with high quality water but the supply meet certain technical requirements such as appropriate water pressure over longer periods of time.

The pipeline network is particularly vulnerable to damage and simultaneously constitutes the most capital-intensive part of a water supply system (up to $70 \%$ of total cost), especially in large cities. It is commonly understood [1] that operating costs are caused chiefly by distributing water from the storage facilities to pipeline connections, from where it is further supplied to the end users. The high failure rate results mainly from the fact that a large number of distribution pipes are concentrated in a rather small area, which incidentally also contributes to higher costs. Distribution pipelines in cities are often

\footnotetext{
${ }^{1}$ Faculty of Process and Environmental Engineering, Lodz University of Technology, ul. Wólczańska 213, 90-924 Łódź, Poland, phone +48 426313790

${ }^{2}$ Company of Water Supply and Sewage Disposal Ltd., ul. Wierzbowa 52, 90-133 Łódź, Poland

*Corresponding author: kamil.kaminski@p.lodz.pl
} 
subjected to repeat mechanical stress, for example, in the proximity of roads. Considering that over half of all failures can be associated with distribution pipes, there is a need to keep them in good technical condition. This, in turn, requires methodical renovation of selected pipeline sections in order to avoid serious water supply breakdowns.

The expert systems have become significantly popular in the last decades [2-4]. In order to create them, artificial intelligence has been employed in the form of genetic algorithms [5], fuzzy logic [6] and artificial neural networks (ANNs). Initially being used to recognize speech or images, they have since been successfully applied in chemistry, medicine and molecular biology, but also in ecology and environmental protection. Likewise, a remarkable interest in the application of artificial neural networks to various prognoses and evaluations has been observed over the past few years. ANNs have been employed to enhance environmental engineering through anticipating soil contamination, emission of nitrous oxide and concentration of polycyclic aromatic hydrocarbons [7, 8], predicting solar activity to facilitate the management of solar power plants [9] and evaluating the performance of cyclone separators [10]. ANNs have also been used for prediction and classification in various problems on the border between environmental engineering and meteorology. One notable example is the application of a neural model coupled with a fuzzy logic system in order to detect the possibility of tornadoes in the states of Kansas and Alabama, described in [11]. Kaur [12] attempted to recognize tornadic circulations in the atmosphere using data from a Doppler weather radar system and MLP (multilayer perceptron). Moreover, self-organizing artificial neural networks and radial basis function networks (RBFN) have been successfully used for the automatic classification of cloud types in satellite images [13,14], which can be very helpful in weather forecasting. Numerous applications of ANNs can be found in the field of atmosphere protection [15] and they are largely possible thanks to the MLP and the RBFN [16].

Artificial neural networks have also been employed to solve problems related to the broadly defined water resource management. A neural model using flexible Bayesian methods was used to predict the degree of exploitation of groundwater and surface water and tested on the Opole Province in Poland [17]. RBFN and MLP networks as well as general regression neural networks (GRNN) were successfully used for evaluating the separation of chromium ions from aqueous solutions with the help of ultrafiltration [18]. MLP networks were also used for modeling the depth profiles of dissolved oxygen in the Thesaurus reservoir on the Nestos river [19]. The multilayer perceptron was utilized to predict algal concentrations in the coastal waters of Hong Kong [20] and in Lake Kasumigaura, the second-largest lake in Japan [21]. Several types of artificial neural networks (including MLP, RBFN and GRNN) were implemented to predict total phosphorus concentrations in the Odra river in Poland [22]. Another interesting example is the application of MLP and RBFN neural networks to the estimation of failure indicators for water distribution networks and water connections [23, 24]. Kutylowska [23] emphasized that determining failure indicators was particularly difficult in the case of distribution networks. It should be noted that failure indicators are among many variables dictating the necessity of renovation, which will be discussed further in the text. Therefore, failure indicators alone may prove insufficient or lead to erroneous decisions, especially when they come with a high degree of uncertainty. MLP was also applied for localization of the damage states in the water supply system in Rzeszow [25]. Ciezak et al. [26] proposed application of autoregressive integrated moving average (ARIMA) model for 
prediction of water demand time series in municipal systems of Wroclaw and Brzeg and compared the results with outcomes obtained for MLP. The forecast quality for the applied ARIMA model and MLP were satisfactory and comparable. Possibilities of water demand predicting by means of ARIMA models and ANNs were also tested for water supply system in Krakow [27]. The neural network model was recommended as a more effective tool, which generates more reliable forecasts. Different variants of self-organizing Kohonen neural networks were also implemented for classification of water pipes diameters [28].

Artificial neural networks seem to be an effective tool in supporting renovation decisions regarding selected parts of a water supply system. The advising system using an ANN is not prone to subjectivity, unlike expert opinions. Nevertheless, exploiting the possibilities offered by neural networks requires comprehensive data, detailing the technical condition of the system. On the other hand, if such a database exists, there is no need to develop an analytic description of the task at hand. The neural network can postulate or abort renovation of a specific part of the system solely on grounds of the relation between the input and the output data.

\section{Characteristics of water supply in Lodz}

The neural network described further in the paper was tested on Lodz - one of the biggest cities in Poland. Water for the needs of Lodz is taken mainly from drilled wells located in the city or in neighbouring towns. The remaining water demand is satisfied by the intake on the Pilica river in Tomaszow Mazowiecki. Currently, daily water consumption of Lodz is equal to about $110,000 \mathrm{~m}^{3}$. The municipal water supply system has been subjected to repairs and renovations since the early 1990s. The renovation plan was established based on expert decisions; however, initially the renovation works concentrated on large pipes transporting water from the intakes outside Lodz and only then the remaining parts of the system were gradually renovated.

Today, Lodz exploits over two thousand kilometers of water supply pipelines including:

- $230 \mathrm{~km}$ of mains,

- $1,170 \mathrm{~km}$ of distribution pipes,

- $600 \mathrm{~km}$ of water connections.

The study was focused on the distribution pipelines, constituting the longest water supply sub-network in the city. In 2013, $48 \%$ of the pipelines were made of cast iron, $32 \%$ were made of polyvinyl chloride (PVC) while the remaining $20 \%$ were asbestos-cement, high-density polyethylene (HDPE) and ductile iron pipes. The age structure of the distribution system was as follows:

- $38.6 \%$ - pipes 31-50 years old,

- $23.6 \%$ - pipes 11-20 years old,

- $14.3 \%$ - pipes older than 50 years,

- $14.0 \%$ - pipes $21-30$ years old,

- $8.5 \%$ - pipes younger than 10 years.

The diverse age structure helped to assemble a large set of data containing information on the technical condition of the water supply system in the city. 


\section{Features of the neural network}

The study employed a feedforward neural network in the form of a multilayer perceptron [29]. A network of this type is formed in three layers, called the input layer, hidden layer and output layer (Fig. 1). In the case of hidden neurons the sigmoid activation function described by equation (1) was used while the output neurons obeyed linear transformation

$$
f(x)=\frac{2}{1+e^{-2 x}}-1
$$

The MLP was trained assuming backpropagation and the Levenberg-Marquardt algorithm [30]. The training consisted in iterative selection of biases and weights of the synaptic connections between the neurons so that the MLP responses to the input data were consistent with the expert decisions concerning renovation of a specific pipeline section. The following encoding rule was accepted:

- 1 - if the expert recommended renovation,

- 0 - if renovation was not suggested.

In order to find the optimal structure of the MLP, networks containing different number of neurons in the hidden layer were tested. Additionally for the same number of hidden neurons training was repeated several times. The sum of the squared differences between the expected value $\{1,0\}$ and the output value was accepted as a selection criterion. Selection of the best structure was made by determining the minimum sum of squared deviations from among the analyzed variants. Finally, after selection the best MLP structure, the output from the neural network took the value 0 or 1 using threshold 0.5 .

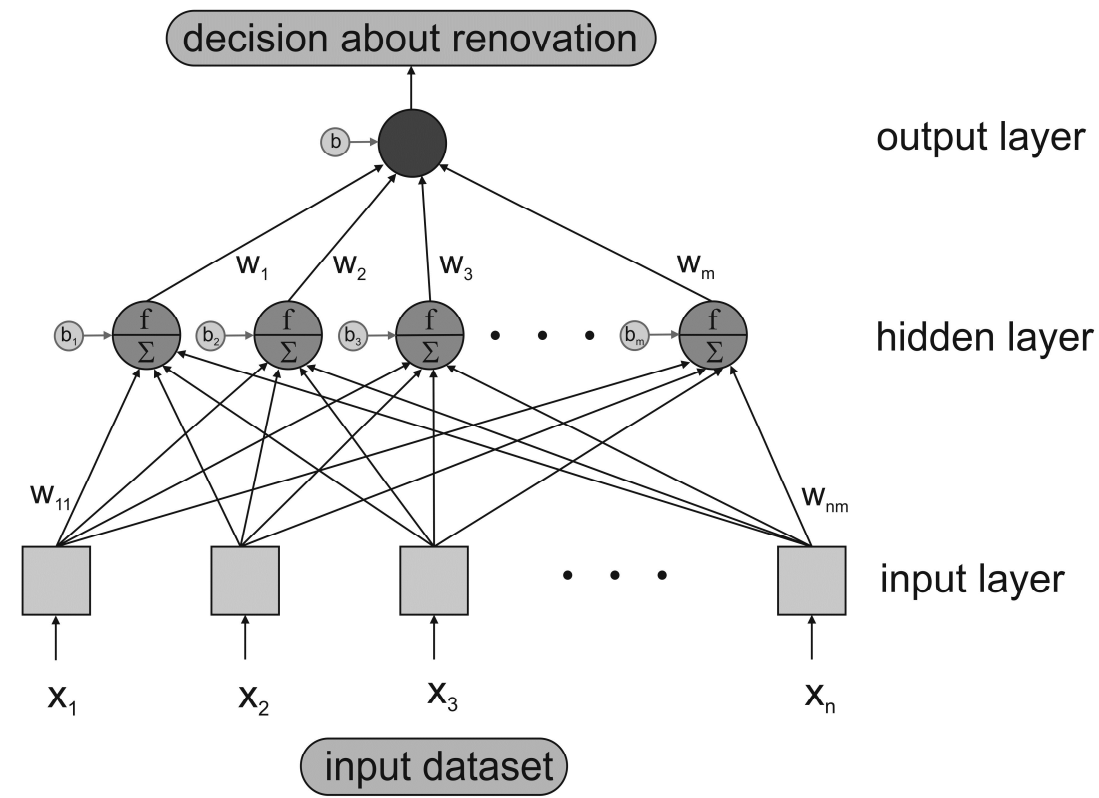

Fig. 1. Structure of the multilayer perceptron (MLP) used in the study 


\section{Description of the MLP input data}

The data set designated for testing the neuron model, developed in order to determine current renovation needs, was extracted from the database of the Company of Water Supply and Sewage Disposal in Lodz. The company maintains extensive electronic records concerning the technical condition of the water supply network as well as the information on completed renovations, carried out over the past twenty one years. Considering the complexity of the water supply infrastructure and the long time span covered by the database, preparation of data fed into the neural model was made using a special version of Mb_GIS Utility software (Geographic Information System) dedicated for water supply companies. The software provides automated analysis and comparison of the spatial information stored in the database. All data available in the database was taken for training and testing MLP.

The data on the water distribution system condition were prepared in such a way so as to introduce them into the neural model. Table 1 shows the components of the set of records used as the input data. The expected network output took on the value 1 or 0 , depending on whether the expert advised conducting or aborting renovation in a specific instance represented by the input vector.

Table 1

Components of the training vectors

\begin{tabular}{|c|c|c|c|}
\hline No. & \multicolumn{2}{|l|}{ Component } & Variation range \\
\hline \multicolumn{4}{|c|}{ Input data } \\
\hline 1 & Pipe diameter & {$[\mathrm{mm}]$} & $100-250$ \\
\hline 2 & $\begin{array}{l}\text { Pipe material } \\
\text { 1. Cast iron } \\
\text { 2. Asbestos-cement } \\
\text { 3. Polyvinyl chloride (PVC) } \\
\text { 4. Steel } \\
\text { 5. High-density polyethylene (HDPE) }\end{array}$ & {$[-]$} & $\{1,2,3,4,5\}$ \\
\hline 3 & Age & [years] & $11-94$ \\
\hline 4 & Failure rate from the last 3 years & [failure/km/year] & $0-8$ \\
\hline 5 & Failure rate from the last 10 years & [failure/km/year] & $0-3.5$ \\
\hline 6 & $\begin{array}{l}\text { Existence of forces affecting the pipeline } \\
1 \text { - yes; } 0 \text { - no }\end{array}$ & {$[-]$} & $\{0,1\}$ \\
\hline \multicolumn{4}{|c|}{ Output data } \\
\hline 1 & $\begin{array}{l}\text { Necessity of renovation } \\
1 \text { - yes; } 0 \text { - no }\end{array}$ & {$[-]$} & $\{0,1\}$ \\
\hline
\end{tabular}

Failures of water supply infrastructure are significantly influenced by the piping material and construction. For this reason, the type of material used for a particular section of the pipeline was considered among the input data to the neuron model. Such an approach required encoding each of the five materials in the form of an integer number (Table 1). The effort was also undertaken to replace the type of material with its theoretical operating time, for example, 80 years with regard to cast iron pipes; however, this idea did not produce satisfactory results. Several tests, where another component representing the length of a given section was added to the input vector, did not improve the results, either. In the latter case, the lack of improvement in the neuron model operation appeared justified, because the information on failures regarding the sections of specific lengths was indirectly contained within the failure coefficients. Besides, the introduction of additional components 
into the teaching vector caused growth of the neural structure and thereby obstacles in successful training.

As the data pertaining to the completed renovations were collected over more than 20 years, the operating time of a given section of the pipeline was calculated up to the point at which a decision was made to renovate it. Furthermore, data were discarded if renovation was encouraged by circumstances other than bad technical condition of the pipeline, such as planned reconstruction or renovation of thoroughfares in the city.

The set of data defined according to the above described procedure was used as the input to the neuron model. Altogether, the database contained over two hundred records:

- 105 records regarding the already-renovated sections of the pipeline system,

- 100 records regarding the pipelines that had not yet been subjected to renovation.

The data were further randomly divided into a training set containing $70 \%$ of all records (143 samples) as well as a validation set and a test set, each containing $15 \%$ of cases from the general database (31 samples each). All the sets were randomly selected from the complete set of data. The training and validation sets were used for training the MLP. The testing set was not used for training but only for assessment of its quality. As a result of iterative training, consisting in the presentation of multiple input vectors together with the corresponding expert decisions, the MLP learned to recognize the necessity of renovation based on the technical condition of a pipeline. As it was mentioned before, when the output signal of the MLP took a value of 0.5 or higher, it was assumed that the section of a pipeline defined by the input vector should be renovated. When the output signal was lower than 0.5 , it was concluded that renovation was not necessary. Application of the above rule proved that the neural network containing five neurons in the hidden layer was the most effective. Using less than five neurons resulted in less accurate responses. When more than five neurons were used, the network became overtrained, i.e. the responses concerning the expert decisions taken from the training set were better but simultaneously much worse with regard to the test set.

\section{Analysis of results}

Examination of the responses generated by the trained neural network revealed agreement with the decisions made by experts for 175 records from the database. In spite of this fact, 30 responses of the MLP were not consistent with the expert decisions. In the majority of these cases (23 records), the MLP qualified a pipeline as requiring renovation, although such actions had not been undertaken in the past (Table 2). Detailed analysis of the input data set demonstrated that 12 of these cases were related to the pipeline sections shorter than $250 \mathrm{~m}$ with at least one failure indicator exceeding a value of 1.0 failure $/ \mathrm{km} /$ year. Usually, such short pipeline sections were not considered by the experts, even if they were characterized by high failure indicators. Also, the MLP selected 4 cast iron pipelines to be renovated due to their age exceeding 65 years. In five cases of PVC pipes, the neural model suggested renovation regardless of pipeline age, because there existed at least one failure indicator having a high value. In 4 of 5 cases, renovation was recommended with regard to relatively young pipeline sections, less than 50 years in operation. One can surmise that the need to renovate these sections was mainly caused by the errors made during the installation of PVC pipes, commonly replacing old grey cast iron pipes in the 1960s and 1970s. 
The neural model identified 7 pipeline sections that had been unnecessarily renovated in the past (Table 3). Usually, the MLP questioned conducting renovation when the pipeline was less than 60 years old (with one exception) and when the failure indicators did not exhibit particularly high values. Such responses of the neuron model seemed substantiated by the fact that the pipelines had been designed for at least 50 years of continuous operation. In two cases, the MLP discarded renovation of asbestos-cement pipes as they were not subjected to mechanical stress.

Table 2

List of pipeline sections singled out by the neuron model as requiring renovation

\begin{tabular}{|c|c|c|c|c|c|c|c|}
\hline $\begin{array}{c}\text { No. of } \\
\text { a pipeline } \\
\text { section } \\
\text { in the } \\
\text { database }\end{array}$ & $\begin{array}{c}\text { Diameter } \\
\text { [mm] }\end{array}$ & $\begin{array}{c}\text { Type of } \\
\text { material }\end{array}$ & $\begin{array}{c}\text { Operating } \\
\text { period } \\
\text { [years] }\end{array}$ & $\begin{array}{c}\text { 3-year failure } \\
\text { indicator } \\
\text { [failure/km/year] }\end{array}$ & $\begin{array}{c}\text { 10-year failure } \\
\text { indicator } \\
\text { [failure/km/year] }\end{array}$ & $\begin{array}{c}\text { Dynamic } \\
\text { load }\end{array}$ & $\begin{array}{c}\text { Expert } \\
\text { decision on } \\
\text { renovation }\end{array}$ \\
\hline 107 & 150 & 1 & 69 & 1.9 & 1.5 & 1 & 0 \\
\hline 129 & 100 & 1 & 87 & 0 & 0.7 & 0 & 0 \\
\hline 130 & 100 & 1 & 61 & 1.3 & 1.1 & 0 & 0 \\
\hline 135 & 150 & 1 & 61 & 2 & 1.1 & 1 & 0 \\
\hline 136 & 100 & 3 & 52 & 0.8 & 0.7 & 0 & 0 \\
\hline 138 & 150 & 1 & 60 & 0.9 & 0.7 & 0 & 0 \\
\hline 143 & 125 & 1 & 66 & 0.8 & 1 & 1 & 0 \\
\hline 144 & 100 & 1 & 55 & 1.8 & 0.8 & 0 & 0 \\
\hline 147 & 200 & 1 & 54 & 1.6 & 1.3 & 0 & 0 \\
\hline 151 & 100 & 1 & 64 & 1.7 & 0.9 & 0 & 0 \\
\hline 152 & 100 & 1 & 61 & 1.3 & 1.5 & 1 & 0 \\
\hline 153 & 100 & 1 & 56 & 1.7 & 0.9 & 0 & 0 \\
\hline 154 & 150 & 3 & 45 & 0 & 1.2 & 0 & 0 \\
\hline 155 & 200 & 1 & 56 & 1.2 & 1.3 & 0 & 0 \\
\hline 166 & 200 & 2 & 62 & 0 & 0.9 & 1 & 0 \\
\hline 178 & 150 & 3 & 43 & 1.1 & 0.6 & 0 & 0 \\
\hline 181 & 100 & 1 & 58 & 1 & 1.1 & 0 & 0 \\
\hline 183 & 150 & 3 & 45 & 1.8 & 0.4 & 1 & 0 \\
\hline 184 & 100 & 1 & 80 & 0.4 & 0.5 & 0 & 0 \\
\hline 189 & 100 & 3 & 49 & 0.5 & 0.8 & 0 & 0 \\
\hline 190 & 125 & 1 & 74 & 0.5 & 0.5 & 0 & 0 \\
\hline 191 & 200 & 1 & 65 & 0.2 & 0.8 & 1 & 0 \\
\hline 203 & 200 & 1 & 65 & 0.4 & & 1 & 0 \\
\hline
\end{tabular}

List of pipeline sections rejected from the renovation plan by the neuron model

\begin{tabular}{|c|c|c|c|c|c|c|c|}
\hline $\begin{array}{c}\text { No. of } \\
\text { a pipeline } \\
\text { section } \\
\text { in the } \\
\text { database }\end{array}$ & $\begin{array}{c}\text { Diameter } \\
{[\mathbf{m m}]}\end{array}$ & $\begin{array}{c}\text { Type of } \\
\text { material }\end{array}$ & $\begin{array}{c}\text { Operating } \\
\text { period } \\
\text { [years] }\end{array}$ & $\begin{array}{c}\text { 3-year failure } \\
\text { indicator } \\
\text { [failure/km/year] }\end{array}$ & $\begin{array}{c}\text { 10-year failure } \\
\text { indicator } \\
\text { [failure/km/year] }\end{array}$ & $\begin{array}{c}\text { Dynamic } \\
\text { load }\end{array}$ & $\begin{array}{c}\text { Expert } \\
\text { decision on } \\
\text { renovation }\end{array}$ \\
\hline 12 & 100 & 1 & 54 & 0 & 0.9 & 1 & 1 \\
\hline 31 & 200 & 1 & 57 & 0.7 & 0.5 & 0 & 1 \\
\hline 32 & 150 & 1 & 49 & 0.7 & 0.7 & 1 & 1 \\
\hline 38 & 250 & 1 & 43 & 1.1 & 0.3 & 1 & 1 \\
\hline 61 & 150 & 2 & 54 & 0.8 & 0.4 & 0 & 1 \\
\hline 85 & 125 & 1 & 64 & 0.6 & 0.7 & 0 & 1 \\
\hline 91 & 100 & 2 & 53 & 0.9 & 0.6 & 0 & 1 \\
\hline
\end{tabular}


As a result of the study a computer program has been created in the MATLAB computing environment. The program allows making decision about renovation of pipelines in Lodz based on factors presented in Table 1. It should be noted that the quality of decisions made by the neuron model depends on the reliability of the data employed in the training process. A relatively low number of failures of the distribution network in Lodz (from 0.21 to 0.26 failure/km/year) (Fig. 2), reported in the years 2010 to 2014, suggests prudent renovation planning. Therefore, the expert decisions concerning the completed renovations of the water supply network could be considered reliable enough in order to train the neuron model.

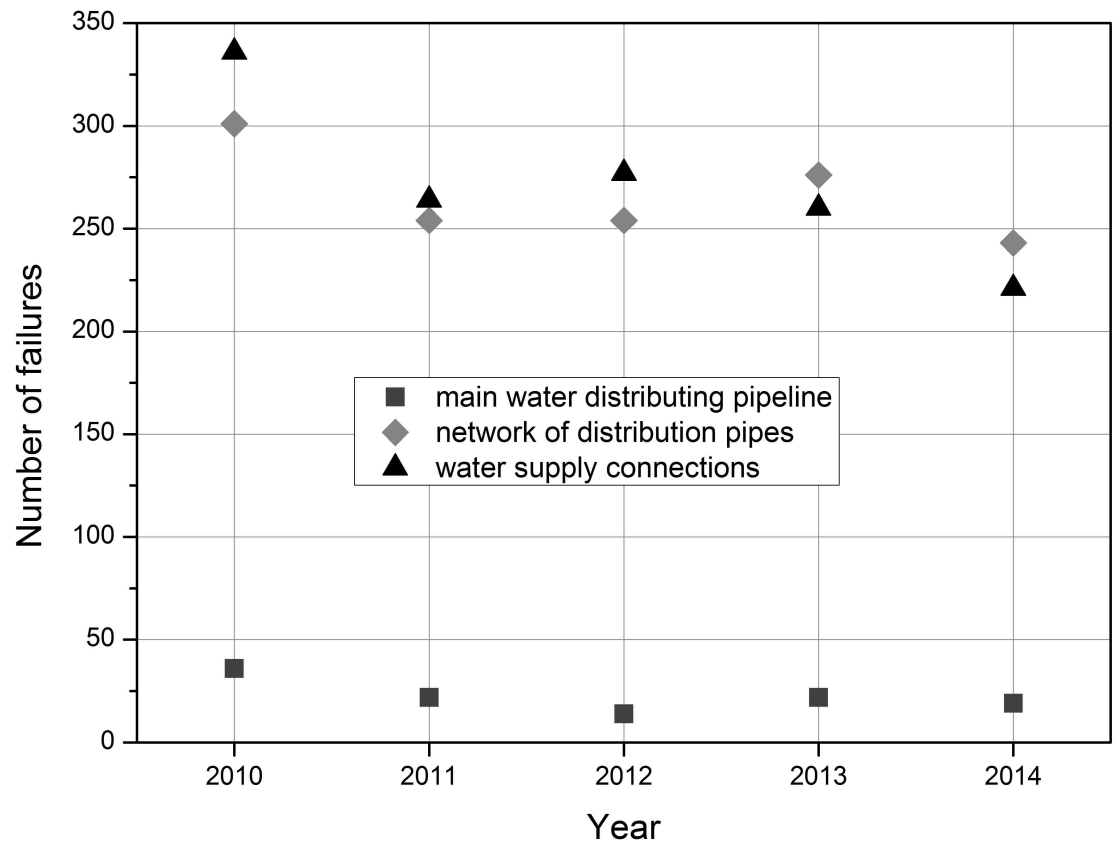

Fig. 2. Number of failures of the water supply system in Lodz in the years 2010 to 2014

\section{Summary and conclusions}

The article suggests using an artificial neuron network MLP type as a tool for supporting renovation decisions, concerning water supply systems in large cities. The method was tested on the water pipelines in Lodz, with the help of data collected routinely over a period of more than 20 years.

During the study, a trained neural network was examined by comparing its responses with expert recommendations made in the past. Although good agreement was achieved between them, a subset of contrary decisions was identified. In the majority of these conflicting cases, the MLP recommended renovation of the pipeline section that had not been previously picked by the experts. Additionally, according to the MLP a few of the completed renovations were unnecessary. Considering the ability of the MLP to transfer the acquired knowledge onto new circumstances, not presented during the training process, the 
neural model can be employed to form current renovation plans, especially in the absence of human experts. However, reliable historical data are required for the MLP to generate objective decisions.

In financial terms, implementing such an expert system by a municipal water and sewage company can help optimize its resources designated for maintaining efficient and uninterrupted operation of the water supply infrastructure.

\section{References}

[1] Hotloś H. Ilościowa ocena wpływu wybranych czynników na parametry i koszty eksploatacyjne sieci wodociągowych (Quantitative effect assessment of selected factors on indicators and operating costs of water-pipe networks). Wrocław: Ofic Wyd Politechniki Wrocławskiej; 2007. http://www.dbc.wroc.pl/ Content/4273/Hotlos.pdf.

[2] Ladopoulos EG. Non-linear real-time expert water management telematics system for leaks control. Water Res. 2013;40:476:482. DOI: 10.1134/S0097807813040076.

[3] Hoang TH, Mouton A, Lock K, De Pauw N, Goethals PLM. Integrating data-driven ecological models in an expert-based decision support system for water management in the Du river basin (Vietnam). Environ Monit Assess. 2013;185:631-642. DOI: 10.1007/s10661-012-2580-6.

[4] Cretescu I, Craciun I, Benchea RE, Kovács Z, Iavorschi A, Sontea V, et al. Development of an expert system for surface water quality monitoring in the context of sustainable management of water resources. Environ Eng Manage J. 2013;12:1721-1734. http://omicron.ch.tuiasi.ro/EEMJ/pdfs/vol12/ no8/20_769_Cretescu_13.pdf.

[5] Nicklow J, Reed P, Savic D, Dessalegne T, Harrell L, Chan-Hilton A, et al. State of the art for genetic algorithms and beyond in water resources planning and management. J Water Resources Plann Manage. 2010;136:412-432. DOI: 10.1061/(ASCE)WR.1943-5452.0000053.

[6] Tchorzewska-Cieslak B. Matrix method for estimating the risk of failure in the collective water supply system using fuzzy logic. Environ Protect Eng. 2011;38:111-118. http://epe.pwr.wroc.pl/2011/ 3_2011/12tchorzewska.pdf.

[7] Kolasa-Więcek A. Use of artificial neural networks in predicting direct nitrous oxide emissions from agricultural soils. Ecol Chem Eng S. 2013;20:419-428. DOI: 10.2478/eces-2013-0030.

[8] Olawoyin R. Application of backpropagation artificial neural network prediction model for the PAH bioremediation of polluted soil. Chemosphere. 2016;161:145-150. DOI: 10.1016/j.chemosphere.2016.07.003.

[9] Wu Y, Wang J. A novel hybrid model based on artificial neural networks for solar radiation prediction. Renew Energy. 2016;89:268-284. DOI: 10.1016/j.renene.2015.11.070.

[10] Selami D, Karadeniz A, Demir NM. Using steepness coefficient to improve artificial neural network performance for environmental modeling. Pol $\mathrm{J}$ Environ Stud. 2016;25:1467-1477. DOI: $10.15244 /$ pjoes/61958.

[11] Wang Y, Yu T-Y. Novel tornado detection using an adaptive neuro-fuzzy system with S-band polarimetric weather radar. J Atmosph Oceanic Technol. 2015;32:195-208. DOI: 10.1175/JTECH-D-14-00096.1.

[12] Kaur G. Neural networks to identify tornadic/nontornadic circulations based on various radar attributes. Intern J Sci Eng Res. 2013;4:1124-1126. http://www.ijser.org/researchpaper\%5CNeural-Networks-toidentify-Tornadic-NonTornadic-Circulations-based-on-various-radar-attributes.pdf.

[13] Liu Y, Xia J, Shi C-X, Hong Y. An improved cloud classification algorithm for China's FY-2C multi-channel images using artificial neural network. Sensors. 2009;9:5558-5579. DOI: 10.3390/s90705558.

[14] Kuril S, Saini I, Saini BS. Cloud classification for weather information by artificial neural network. International J Appl Phys Math. 2013;3:28-30. DOI: 10.7763/IJAPM.2013.V3.167.

[15] Asadollahfardi G, Zangooei H, Aria SH. Predicting PM2.5 concentrations using artificial neural networks and Markov chain, a case study Karaj City. Asian J Atmosph Environ. 2016;10:67-79. DOI: 10.5572/ajae.2016.10.2.067.

[16] Kaminski W, Tomczak E. An integrated neural model for drying and thermal degradation of selected products. Drying Technol. 1999, 17:7-8, 1291-1301. DOI: 10.1080/07373939908917615.

[17] Kolasa-Więcek A. Exploitation of water resources of the Opole province - forecasting with the use of artificial neural networks. Ecol Chem Eng S. 2010;17:363-371. http://tchie.uni.opole.pl/freeECE/ S_17_3/KolasaWiecek_17(S3).pdf. 
[18] Korus I, Piotrowski K. Neural network model prediction of chromium separation in polyelectrolyteenhanced ultrafiltration. Ecol Chem Eng A. 2014;21:377-385. DOI: 10.2428/ecea.2014.21(3)31.

[19] Sentas A, Psilovikos A, Psilovikos T, Matzafleri N. Comparison of the performance of stochastic models in forecasting daily dissolved oxygen data in dam-Lake Thesaurus. Desalin Water Treatm. 2016;57:11660-11674. DOI: 10.1080/19443994.2015.1128984.

[20] Lee JHW, Huang Y, Dickman M, Jayawardena AW. Neural network modelling of coastal algal blooms. Ecol Modelling. 2003;159:179-201. DOI: 10.1016/S0304-3800(02)00281-8.

[21] Wei B, Sugiura N, Maekawa T. Use of artificial neural network in the prediction of algal blooms. Water Res. 2001;35:2022-2028. DOI: 10.1016/S0043-1354(00)00464-4.

[22] Możejko J, Gniot R. Application of neural networks for the prediction of total phosphorus concentrations in surface waters. Pol J Environ Stud. 2008;17:363-368. http://www.pjoes.com/pdf/17.3/363-368.pdf.

[23] Kutyłowska M. Neural network approach for failure rate prediction. Eng Failure Anal. 2015;47:41-48. DOI: 10.1016/j.engfailanal.2014.10.007.

[24] Kutyłowska M. Prediction of water conduits failure rate - comparison of support vector machine neural network. Ecol Chem Eng A. 2016;23:147-160. DOI: 10.2428/ecea.2016.23(2)11.

[25] Rojek I, Studziński J. Sieci neuronowe w lokalizacji awarii w sieci wodociągowej (Application of neuronal networks for localization of a failure in the water supply network). Studia i Materiały Informatyki Stosowanej. 2012;9:29-34. http://repozytorium.ukw.edu.pl/handle/item/3539.

[26] Cieżak W, Siwoń Z, Cieżak J. Zastosowanie sztucznych sieci neuronowych do prognozowania szeregów czasowych krótkotrwałego poboru wody w wybranych systemach wodociągowych (Artificial neural networks for predicting time series of water demand in selected municipal water supply systems). Ochrona Środ. 2006:39-44. http://www.os.not.pl/docs/czasopismo/2006/Ciezak_1-2006.pdf.

[27] Muszyński K. Metoda sztucznych sieci neuronowych w prognozowaniu bieżącym zapotrzebowania na wodę w Krakowie (Artificial neural network method in current prediction of water demand in Krakow), Rozprawa doktorska (PhD Thesis). Kraków: Politechnika Krakowska im. Tadeusza Kościuszki; 2012. https://suw.biblos.pk.edu.pl/downloadResource\&mId=979033.

[28] Dawidowicz J. Ocena średnic przewodów wodociągowych za pomocą sieci neuronowych Kohonena (Evaluation of water pipe diameters using Kohonen neural networks). J Civil Eng, Environ Architect. 2015;62:43-64. DOI: 10.7862/rb.2015.4.

[29] Kamiński W, Strumiłło P, Tomczak E. Zastosowanie sztucznej inteligencji w rozwiązywaniu wybranych problemów ochrony atmosfery (Application of artificial intelligence systems for solving some environmental problems). Łódź: PAN Oddział w Łodzi; 2005.

[30] Osowski S. Sieci neuronowe w ujęciu algorytmicznym (An algorithmic approach to neural networks). Warszawa: WNT; 1996. 